\title{
Protein requirement of baby pigs
}

2.* Requirement on high-fat diets and effect of replacing carbohydrate by fat

\author{
By M. J. MANNERS AND M. R. McCREA \\ Department of Animal Husbandry, School of Veterinary Science, \\ University of Bristol
}

(Received 29 November 1962-Revised 25 February 1963)

Our earlier work with low-fat diets (Manners \& McCrea, I962) had shown no advantage in giving more than $25 \%$ crude protein to piglets over the period from 2 to 28 days of life. Our aims in the experiments now described were to determine if the requirement for protein is greater when high-fat diets are used, to compare fat and carbohydrate as energy sources, and to test the effect of homogenization on the utilization of dietary fat. The three experiments are numbered consecutively to those reported in the previous paper (Manners \& McCrea, 1962). In the first (Expt 4) a control low-fat diet was compared with three diets containing different quantities of protein and in which $9 \%$ lard replaced some of the maize starch in order to determine the effect of fat on protein requirements; in the second (Expt 5) diets containing $2 \mathrm{I} \%$ fat derived from dried whole milk and different quantities of protein were compared; in the third (Expt 6) the effect of a diet containing $20 \%$ lard that had been melted before incorporation was compared with the effect of a diet containing the same amount of emulsified lard. A third diet in which an equicalorific amount of glucose replaced the lard was included in the comparison in Expt 6.

\section{EXPERIMENTAL}

\section{Experimental design}

A randomized block design was used. Four treatments were replicated eight times in Expt 4 and six times in Expt 5, and three treatments were replicated six times in Expt 6. The significance of differences between treatments was tested by analysis of variance.

\section{Animals}

Large White $\times$ Wessex piglets were used in Expts 4 and 5. In Expt 6 two blocks of pure-bred Wessex, two blocks of Large White $\times$ Wessex and two blocks of Large White $\times$ Landrace piglets were used.

\section{Diets and feeding}

The energy values of the diets were estimated from the values in Table 1. As suggested by Maynard (1944) the average Atwater factors of 4,9 and 4 for protein, fat

\footnotetext{
* Paper no. I : Brit. F. Nutr. (1962), 16, 475.
} 
and carbohydrate were not used, but reference was made to the original table by Atwater (reproduced by Maynard, 1944) in which the sources of protein, fat and carbohydrate are taken into account in estimating the available-energy value of each of these food constituents. Values for glucose, sucrose, maize starch and lactose were estimated from their gross energy values (Widdowson, I955; Hawk, Oser \& Summerson, 1954), availability was arbitrarily assumed to be $98 \%$, and allowance was made for moisture content. Details of the diets used in the three experiments are given in Tables 2 and 3 .

\section{Table r. Values (kcal/g) used in the estimation of the energy value of diets (see p. 359)}

Lard and cod-liver oil
Dried whole milk"
Dried separated milk*
Casein"
DDS/DG $†$
Dried yeast
Sucrose
Lactose
Glucose
Maize starch

$8 \cdot 90$
$4 \cdot 86-4 \cdot 95$
$3 \cdot 35-3 \cdot 38$
$3 \cdot 72-3 \cdot 74$
$3 \cdot 81$
$3 \cdot 22$
$3 \cdot 88$
$3 \cdot 80$
3.35
3.62

* Energy values were calculated from the fat, protein and nitrogen-free extract percentages, which varied from one sample to another.

+ A mixture of dried distiller's solubles (30 parts) and dried grains (70 parts).

Expt 4. A low-fat control diet based on the results of earlier experiments (Manners \& McCrea, I962) was compared with three similar diets in which $9 \%$ lard replaced some of the maize starch, and whose crude-protein contents were $22 \cdot 0,28 \cdot 0$ and $35.5 \%$. These levels of protein were such that the range of the calculated energy:protein ratios was approximately the same as that of the low-fat diets in Expt I of our earlier studies. Diet $O$ provided $14.6 \mathrm{kcal} / \mathrm{g}$ crude protein, which ratio had given the best results with low-fat diets (Manners \& McCrea, r962). In diets $\mathrm{P}$ and $\mathrm{N}$ the energy: protein ratios were narrower and wider respectively. The lard was melted and poured into the diet in the food mixer; half-way through the mixing process the diet was rubbed through a sieve of $4 \mathrm{~mm}$ mesh. Diets were stored at 10-1 $4^{\circ}$ and were not kept for more than a month. The piglets were fed twice daily as in Expt 2 of Manners \& McCrea (1962). For the first 3 days the diets were mixed with $200 \mathrm{ml}$ cow's milk/feed. For the remainder of the experiment they were mixed with water at the rate of $\mathrm{I} \mathrm{ml}$ water/g diet.

Expt 5 . The four diets contained $75.5 \%$ dried whole milk, which supplied $21 \%$ fat in the total diet. They contained different amounts of casein and glucose, thus providing a range of energy:protein ratios of from $12 \cdot 2$ to $22.6 \mathrm{kcal} / \mathrm{g}$ crude protein. No liquid cow's milk was given. It was necessary to add $3 \mathrm{ml}$ water $/ \mathrm{g}$ diet to make a satisfactory gruel because of the high fat content of the diets. The amount of diet offered was $80 \%$ of that in previous experiments (see Fig. I, Manners \& McCrea, r962), which compensated to some extent for the bulkiness of the gruel without reducing daily energy intake below earlier levels. However, daily protein, mineral 
and vitamin intakes were reduced by the smaller intake of solids. Otherwise the procedure was as in Expt 4.

Expt 6. Each of the three diets provided $1 \times \cdot 2 \mathrm{kcal} / \mathrm{g}$ crude protein. This narrow ratio was chosen to ensure protein adequacy. The glucose content of the control lowfat diet $(\mathrm{U})$ was calculated on the assumption that $53 \cdot \mathrm{r} 3 \mathrm{lb}$ glucose were equivalent

\section{Table 2. Expts 4 and 5. Composition of diets used}

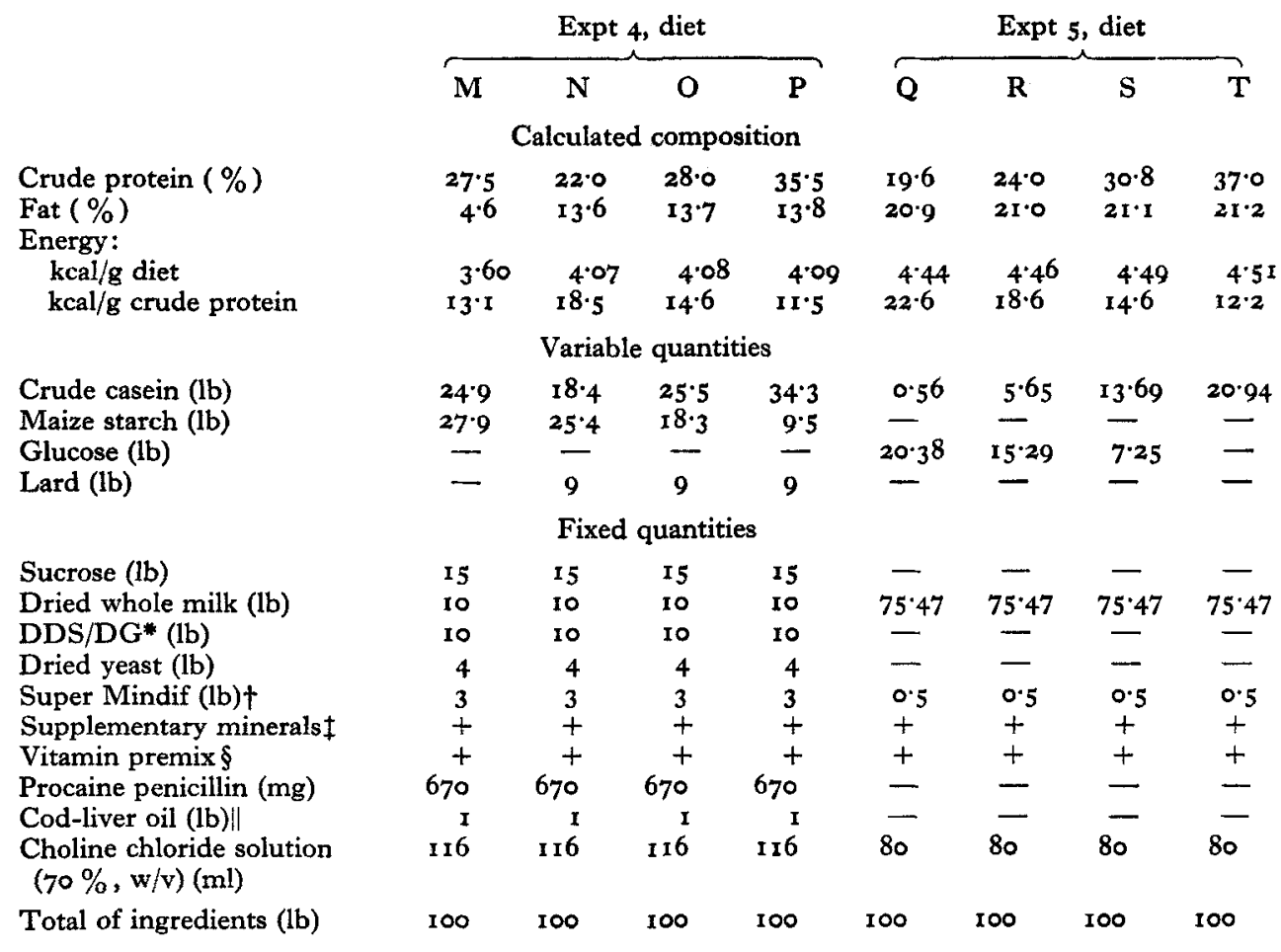

* See Table r.

† A proprietary mineral mixture (Boots Pure Drug Co. Ltd) containing $17 \cdot 4 \%$ calcium, $I I \cdot 4 \%$ phosphorus, $0.75 \%$ sulphur, $0.24 \%$ iron, $30 \% \mathrm{NaCl}$, 1800 p.p.m. copper, 300 p.p.m. cobalt, 5 I0 p.p.m. manganese and 240 p.p.m. iodine.

$f$ Expt 4: $1025 \mathrm{~g} \mathrm{Ca}_{3}\left(\mathrm{PO}_{4}\right)_{2}$, $105.6 \mathrm{~g} \mathrm{KCl}, 4.476 \mathrm{~g} \mathrm{MnSO}_{4} \cdot 4 \mathrm{H}_{2} \mathrm{O}, 33.4 \mathrm{~g}$ calcined magnesite and $145.6 \mathrm{~g}$ iron and ammonium citrate. Expt $5: 806.2 \mathrm{~g} \mathrm{Ca}_{3}\left(\mathrm{PO}_{4}\right)_{2}, 145.149 \mathrm{~g}$ iron and ammonium citrate and $7.379 \mathrm{~g} \mathrm{MnSO}_{4} \cdot 5 \mathrm{H}_{2} \mathrm{O}$.

$\S$ Expt 4: $350 \mathrm{mg} \alpha$-tocopheryl acetate, $94 \mathrm{mg}$ riboflavin, $576 \mathrm{mg}$ calcium pantothenate, rog $\mathrm{mg}$ pyridoxine hydrochloride, $50 \mathrm{mg}$ folic acid, $4400 \mu \mathrm{g}$ cyanocobalamin. Expt 5: 72000 i.u. vitamin A, I8 800 i.u. vitamin $D_{3}, 1 \cdot 360 \mathrm{~g}$ nicotinic acid, $350 \mathrm{mg} \alpha$-tocopheryl acetate, $34 \mathrm{I} \mathrm{mg}$ calcium pantothenate, $53 \mathrm{mg}$ thiamine hydrochloride, $50 \mathrm{mg}$ folic acid, $36 \mathrm{mg}$ menaphthone, $17 \mathrm{mg}$ pyridoxine hydrochloride, $7 \mathrm{mg}$ biotin and $3667 \mu \mathrm{g}$ cyanocobalamin.

II Containing 362874 i.u. vitamin $A$ and 45359 i.u. vitamin $D_{3}$ per lb.

in energy value to $20 \mathrm{lb}$ lard. The lard for use in diets $\mathrm{V}$ and $\mathrm{W}$ was stored at $2^{\circ}$. Glycerol monostearate was included to help to stabilize the emulsion in diet $\mathrm{W}$ and was also added to diets $U$ and $V$. Diet $V$ was rubbed through a sieve of $3 \mathrm{~mm}$ mesh after mixing to break down any lumps and stored at $2^{\circ}$ because of its high fat content. Diet $\mathrm{U}$ and the basal part of $\operatorname{diet} \mathrm{W}$ were stored at $10-14^{\circ}$. Diet $\mathrm{W}$ was made up as 
required at feeding time by adding an emulsion of lard and glycerol monostearate in water to the other ingredients in the feeding trough. The emulsifier operated at about I $000 \mathrm{lb} / \mathrm{in}^{2}$ and most fat globules produced were below $5^{-6} \mu \mathrm{m}$ in diameter. The quantities of certain minerals and of most vitamins were increased in all three diets of Expt 6 so that vitamin and mineral intakes would be approximately equal to those in Expt 4, despite the lower daily intake of the high-fat diets in Expt 6. No liquid

\section{Table 3. Expt 6. Composition of diets used}

\author{
Crude protein ( \%) \\ Fat ( \%) \\ Energy: \\ $\mathrm{kcal} / \mathrm{g}$ diet \\ kcal/g crude protein
}

Glucose (lb)

Lard (lb)

Dried separated milk (lb)
Crude casein (lb)
Glycerol monostearate (lb)
Super Mindif (lb)*
Supplementary minerals $\dagger$
Vitamin premix $\ddagger$
Choline chloride solution $(70 \%, w / v)(\mathrm{ml})$
Total of ingredients $(\mathrm{lb})$

Calculated composition

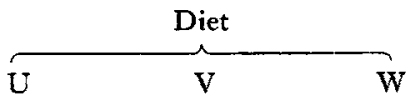

Variable quantities

$53 \cdot 13$

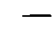

Fixed quantities

$\begin{array}{cc}40 \cdot 0 & 40 \cdot 0 \\ 20 \cdot 8 & 20 \cdot 8 \\ & \\ 4 \cdot 48 & 4 \cdot 48 \\ \text { II.2 } & \text { II. } 2\end{array}$

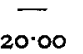

(melted)

$20 \cdot 00$ (homogenized)

$\begin{array}{ccc}44.00 & 44.00 & 44.00 \\ 29.70 & 29.70 & 29.70 \\ 1.25 & 1.25 & 1.25 \\ 0.5 & 0.5 & 0.5 \\ + & + & + \\ + & + & + \\ 96 & 96 & 96 \\ 133.13 & 100.0 & 100.0\end{array}$

* A proprietary mineral mixture (Boots Pure Drug Co. Ltd) containing $17.4 \%$ calcium, II.4\% phosphorus, $0.75 \%$ sulphur, $0.24 \%$ iron, $30 \% \mathrm{NaCl}$, 1800 p.p.m. copper, 300 p.p.m. cobalt, 5 IO p.p.m manganese and 240 p.p.m. iodine.

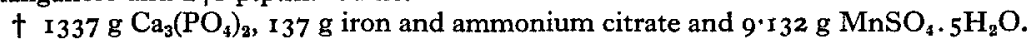

I 195552 i.u. vitamin $A, 48888$ i.u. vitamin $D_{3}, \quad 1453 \mathrm{~g}$ nicotinic acid, $525 \mathrm{mg}$ calcium pantothenate, $350 \mathrm{mg} \alpha$-tocopheryl acetate, $107 \mathrm{mg}$ thiamine hydrochloride, $50 \mathrm{mg}$ folic acid, $36 \mathrm{mg}$ menaphthone, $26 \mathrm{mg}$ pyridoxine hydrochloride, $7 \mathrm{mg}$ biotin and $375 \mathrm{I} \mu \mathrm{g}$ cyanocobalamin.

cow's milk was given. The feeding scale used in earlier experiments was abandoned in favour of a simpler scale, namely, a daily food intake providing $250 \mathrm{kcal} / \mathrm{kg}$ live weight. Food in the form of gruel was given twice daily to provide $125 \mathrm{kcal} / \mathrm{kg}$ at each feed, except for the first feed after caging, which provided $62.5 \mathrm{kcal} / \mathrm{kg}$. Diet $\mathrm{U}$ was found to need $2 \mathrm{ml}$ water $/ \mathrm{g}$ to make a suitable gruel and diet $\mathrm{V}$ needed $3 \mathrm{ml}$. Hot water $\left(52-54^{\circ}\right)$ was used. The dilution of the emulsion for diet $W$ was the same as for diet $\mathrm{V}$. Thus the intakes of water and dietary dry matter with diets $\mathrm{V}$ and $\mathrm{W}$ were identical. In addition, by coincidence, the total weight of water and diet in the gruels was the same with all three diets. 


\section{Management}

The piglets were removed from their dams when $2-2 \frac{1}{2}$ days old and were given the experimental diets until they were either I4 (Expt 6) or 28 (Expts 4 and 5) days old. Drinking water was always supplied $a d$ lib. If piglets were not from dams vaccinated against Escherichia coli infection they were given a subcutaneous injection of $5 \mathrm{ml}$ of a homologous hyper-immune serum at 2 and at $\mathrm{x} 6$ days of age. General management was as in Expts I-3 of Manners \& McCrea (1962).

\section{RESULTS}

\section{Experiment 4}

Two piglets on diet $\mathrm{O}$ grew extremely slowly, became emaciated, and were killed, one at $\mathrm{I} 4$ and the other at 24 days of age. A piglet on diet M scoured persistently and was removed from the experiment. In consequence, only five complete blocks were available for statistical analysis; results for them are summarized in Table 4. The results for the incomplete blocks supported those given in Table 4 and were considered in arriving at the conclusions set out below.

\section{Table 4. Expt 4. Summary of results}

Protein content of diet ( $\%$ )

Fat content of diet ( $\%)$

No. of piglets

Mean 2nd-day weight (lb)

Mean daily gain from and to $14^{\text {th }}$ day (lb)

Mean food eaten/lb gain, 2nd-I 4th day (lb)

Mean daily gain from 2 nd to 28 th day (lb)

Mean food eaten/lb gain, 2nd-28th day (lb)

Mean 28th-day weight (lb)

$\begin{array}{lcccccc}\overbrace{\mathrm{M}} & \mathrm{N} & \mathrm{O} & \mathrm{P} & \overbrace{P<0.05} \begin{array}{c}P<0.01 \\ \text { Diet }\end{array} & \begin{array}{c}\text { Least significant } \\ \text { difference }\end{array} \\ 27.5 & 22.0 & 28.0 & 35.5 & - & - \\ 4.6 & 13.6 & 13.7 & 13.8 & - & - \\ 5 & 5 & 5 & 5 & - & - \\ 3.79 & 3.87 & 3.97 & 3.92 & - & - \\ 0.273 & 0.172 & 0.172 & 0.277 & 0.065 & 0.091 \\ 1.20 & 1.76 & 1.85 & 1.33 & 0.41 & 0.58 \\ 0.545 & 0.392 & 0.405 & 0.532 & 0.093 & 0.130 \\ 1.07 & 1.20 & 1.18 & 1.10 & 0.11 & - \\ 17.93 & 13.93 & 14.49 & 17.70 & 2.41 & 3.38\end{array}$

Gain in weight. Fig. I shows the mean growth curves of the piglets. It can be seen that piglets on diets $\mathrm{M}$ and $\mathrm{P}$ grew at almost the same rate with no check in growth at any stage. On the other hand, piglets on diets $\mathrm{N}$ and $\mathrm{O}$ suffered a check after the $5^{\text {th }}$ day of life when liquid milk was withdrawn. At 28 days of age the difference in weight between the piglets on these two pairs of treatments was more than $3 \mathrm{lb}$. The differences between piglets on diet $\mathrm{P}$ and on $\operatorname{diet} \mathrm{N}$ and between those on $\operatorname{diet} \mathrm{M}$ and on diets $\mathrm{N}$ and $\mathrm{O}$ were significant at the $\mathrm{I} \%$ level and the difference between piglets on diet $\mathrm{P}$ and on diet $\mathrm{O}$ was significant at the $5 \%$ level.

Economy of food conversion. In the analysis of the five complete blocks of the experiment the differences in economy of food conversion from 5 to 28 days were not significant. However, it was possible to make valid comparisons between seven blocks 
in which diets $\mathrm{M}, \mathrm{N}$ and $\mathrm{P}$ were represented, and in this analysis the economy of food conversion of the piglets on diet $\mathrm{N}$ was found to be poorer $(P<0.0 \mathrm{I})$ than that of the piglets on the other two diets.

More detailed analysis of economy of food conversion showed that the greatest differences between diets were in the period from 2 to 14 days of age, and over this

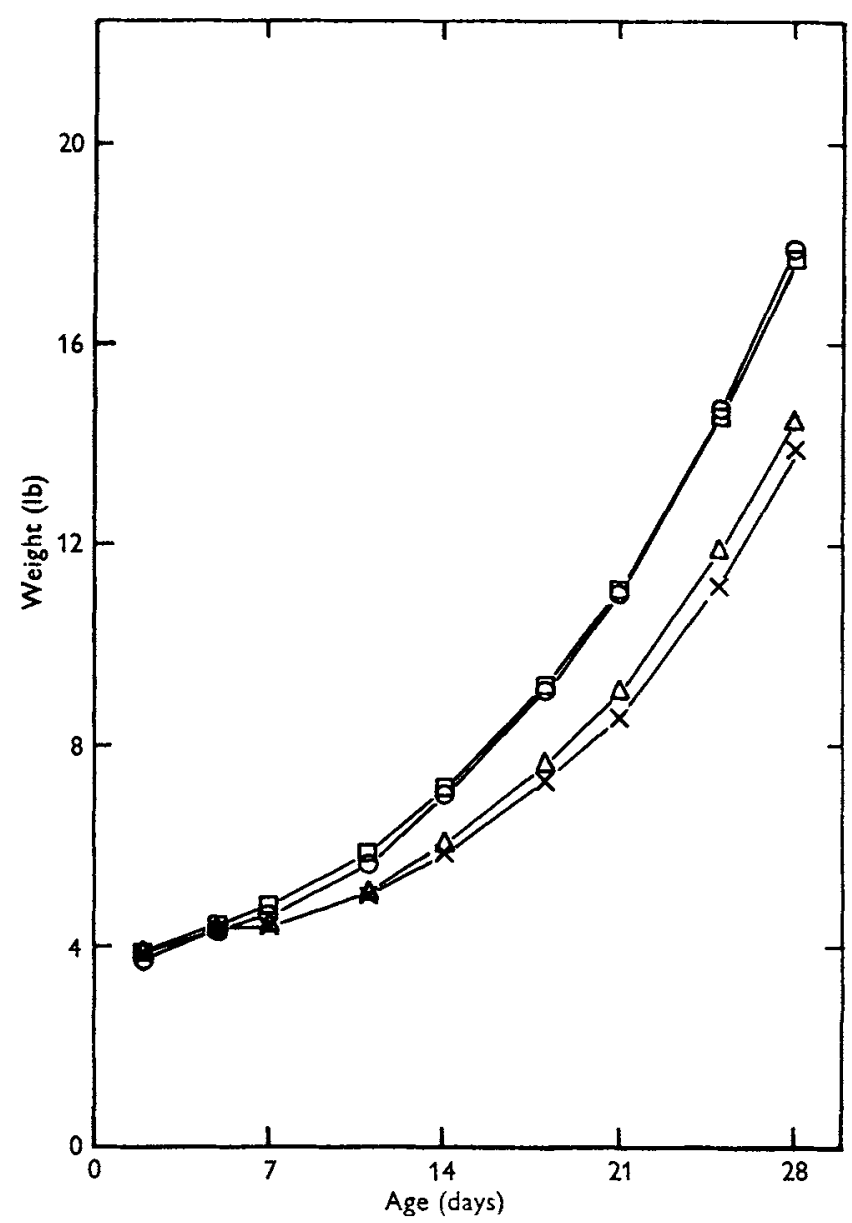

Fig. I. Expt 4. Mean growth curves for groups of five piglets. $0-0$, diet $\mathrm{M}(28 \%$ protein, $4 \%$ fat $) ; x-x$, diet $\mathrm{N}(22 \%$ protein, $13 \%$ fat $) ; \Delta-\Delta$, diet $\mathrm{O}(28 \%$ protein, $13 \%$ fat); $\square-\square$, diet $P$ (36\% protein, r $3 \%$ fat).

period diets $\mathrm{N}$ and $\mathrm{O}$ were both significantly inferior $(P<0.05)$ to diets $\mathrm{M}$ and $\mathrm{P}$. Calculations were made of the weights of food required per unit weight gain in successive 3- to 4-day periods throughout the experiment (for calculation the quantity of liquid cow's milk given at the beginning of the experiment was converted into the equivalent weight of diet with $90 \%$ dry matter). The resultant mean values were plotted against weight in Fig. 2, which shows that on all four diets economy of food conversion improved as the piglets became heavier. From $7 \frac{1}{2} \mathrm{lb}$ body-weight onwards piglets on diet $M$ showed uniformly good food conversion efficiency, and 


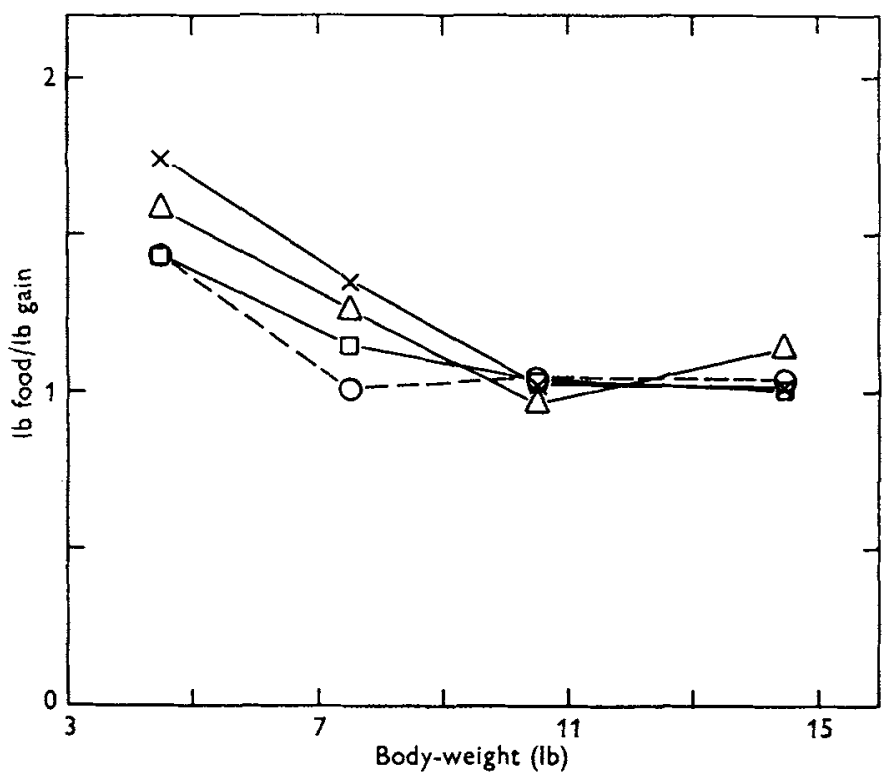

Fig. 2. Expt 4. Changes in economy of food conversion of piglets with increasing weight. Means for $3-6,6-9,9-12$ and $12-17 \mathrm{lb}$ weight. $0--0$, diet $\mathrm{M}$ (28\% protein, $4 \%$ fat); $\times-\times$, diet N (22 \% protein, $13 \%$ fat); $\Delta-\Delta$, diet O (28\% protein, I $3 \%$ fat); $\square-\square$, diet $P$ ( $36 \%$ protein, $\mathrm{r}_{3} \%$ fat).

Table 5. Expt 5. Summary of results

Protein content of diet $(\%)$ Fat content of diet (\%)

No. of piglets

Mean 2nd-day weight (lb)

Mean I 4 th-day weight (lb)

Mean 28th-day weight (lb)

Mean food eaten/lb gain,

2nd-I th day (lb)

Mean food eaten/lb gain, and-28th day (lb)

\begin{tabular}{|c|c|c|c|c|c|c|}
\hline \multicolumn{4}{|c|}{ Diet } & \multicolumn{3}{|c|}{ Least significant difference } \\
\hline $\mathbf{Q}$ & $\mathbf{R}$ & $\mathrm{S}$ & $\mathbf{T}$ & $P<0.05$ & $P<0.01$ & $P<0.001$ \\
\hline $19 \cdot 6$ & $24 \cdot 0$ & $30 \cdot 8$ & $37 \cdot 0$ & - & - & - \\
\hline $20 \cdot 9$ & $2 I \cdot 0$ & $2 r \cdot I$ & $2 I \cdot 2$ & $一$ & - & 一 \\
\hline 6 & 6 & 6 & 6 & - & - & 一 \\
\hline $3 \cdot 98$ & 4.05 & $3 \cdot 79$ & $3 \cdot 76$ & - & - & 一 \\
\hline $6 \cdot 37$ & $7 \cdot 17$ & 7.08 & $7 \cdot 18$ & 一 & 一 & - \\
\hline 12.97 & I 5.79 & $16 \cdot 35$ & $17 \cdot 24$ & 一 & - & 一 \\
\hline$I \cdot 40$ & $I \cdot 2 I$ & $x \cdot 06$ & I'00 & 0.15 & 0.21 & 0.29 \\
\hline$I \cdot 2 I$ & 1.07 & 1.01 & 0.93 & $0.1 \mathrm{I}$ & 0.15 & 0.21 \\
\hline
\end{tabular}

Rates of gain were found to have been influenced by differences in initial weight (owing to a mistake in the allocation of piglets to the experimental treatments). After analysis of covariance the adjusted mean daily live-weight gains were:

From 2nd to 14 th day (lb)

$\begin{array}{ll}\text { Diet Q } & \text { Diet R } \\ 0.189 & 0.239 \\ 0.333 & 0.426\end{array}$

Diet S

Diet T

From 2nd to 28 th day (lb)

0.426

0.288

0.500

0.302

0.540

Level of significance of treatment comparisons:

$\begin{array}{cccccc}\mathrm{Q} \text { and } \mathrm{R} & \mathrm{Q} \text { and } \mathrm{S} & \mathrm{Q} \text { and } \mathrm{T} & \mathrm{R} \text { and } \mathrm{S} & \mathrm{R} \text { and } \mathrm{T} & \mathrm{S} \text { and } \mathrm{T} \\ 5 \% & 0.1 \% & 0.1 \% & 5 \% & 5 \% & \mathrm{NS} \\ \mathrm{I} \% & 0.1 \% & 0.1 \% & 5 \% & 1 \% & \mathrm{NS}\end{array}$

NS, not significant. 
piglets on the other three diets achieved equally good gross feed conversion at about IO $\frac{1}{2} \mathrm{lb}$ body-weight. There was, on the average, $13 \%$ more energy per unit of weight in the lard-containing diets than in the control low-fat diet $\mathrm{M}$. Consequently less of diets $\mathrm{N}, \mathrm{O}$ and $\mathrm{P}$ should have been needed if they had been utilized as efficiently as $\operatorname{diet} \mathrm{M}$.

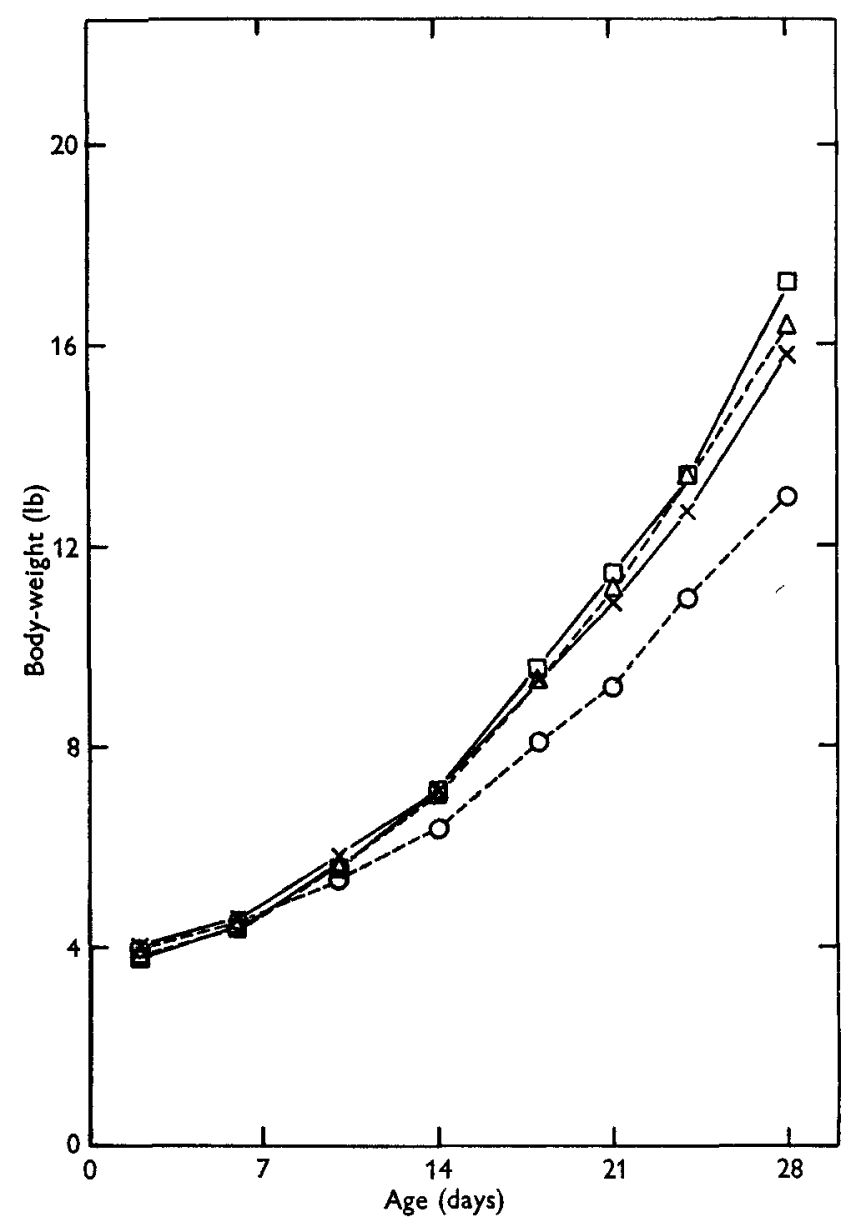

Fig. 3. Expt 5. Mean growth curves for groups of six piglets. $0---0$, diet $Q$ (20\% protein); $\times-\times$, diet R (24\% protein); $\Delta---\Delta$, diet S (31\% protein); $\square-\square$, diet T (37\% protein).

In experiments covering the period in which the piglet's digestive system is developing, those on diets which support superior growth in very early life will mature more rapidly than piglets on less satisfactory diets and, at a given age, will be capable of more efficient food conversion. This greater efficiency will accentuate differences in food conversion by piglets on the different diets when comparisons are made over a fixed time interval, as we have done in our experiments. 


\section{Experiment 5}

The diets in this experiment differed physically in two ways from those used in the earlier trials. First, they did not mix readily with cold water and it was found necessary to soak them for some hours before feeding. Secondly, the amount of water needed to

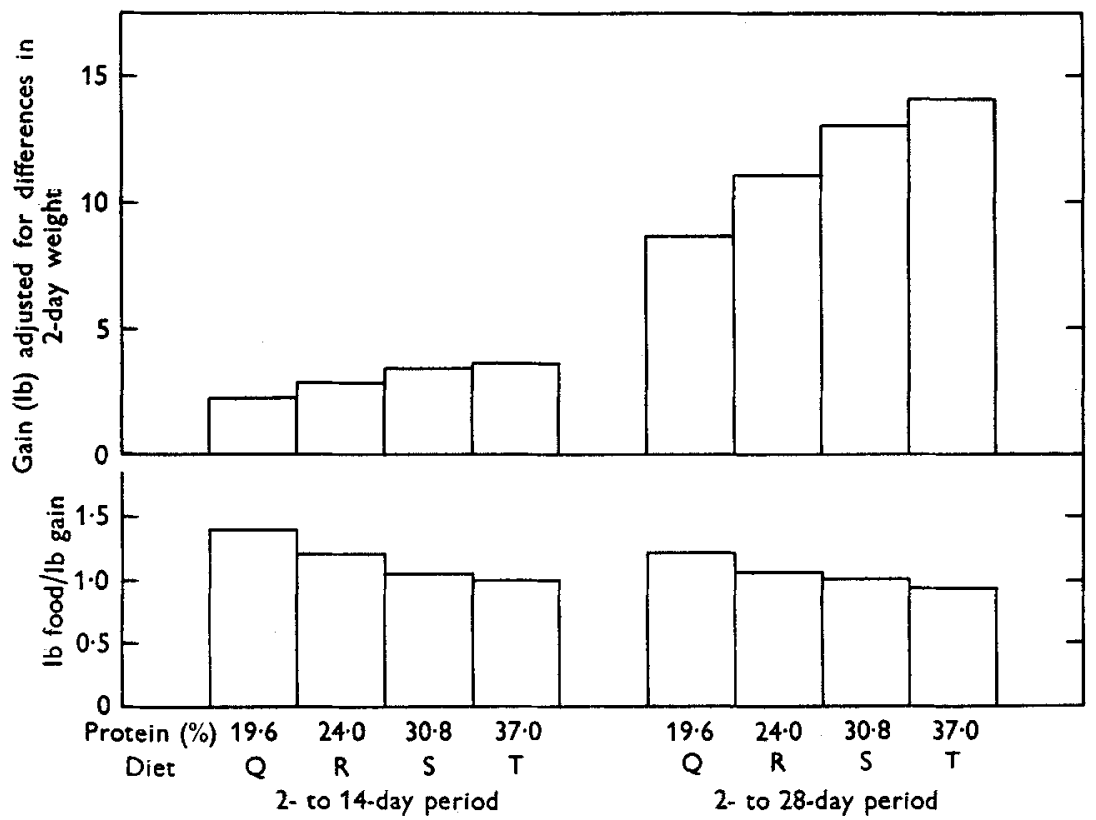

Fig. 4. Expt 5. Histograms showing mean weight gain and efficiency of food conversion for groups of six piglets. Diet Q, $20 \%$ protein; diet R, $24 \%$ protein; diet S, 31 \% protein; diet $\mathrm{T}, 37 \%$ protein.

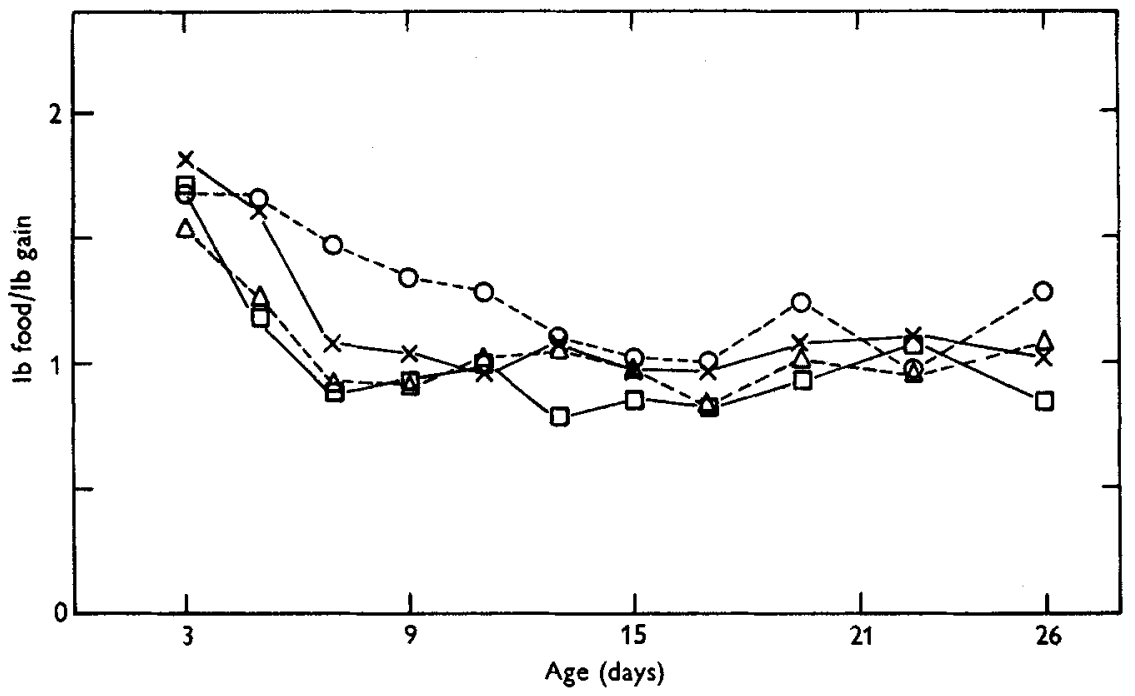

Fig. 5. Expt 5. Changes in economy of food conversion of piglets with increasing age. $0--0, \operatorname{diet} \mathrm{Q}$ (20\% protein); $\times-\times, \operatorname{diet} \mathrm{R}(24 \%$ protein); $\Delta---\Delta, \operatorname{diet} \mathrm{S}$ (3I \% protein); $\square-\square$, diet $T$ (37\% protein). 
make the diets into a gruel was three times that needed in most of the previous experiments. Despite the fact that intake of solids was only $80 \%$ of that in earlier experiments, the piglets occasionally lost appetite during the $3^{\text {rd }}$ and $4^{\text {th }}$ weeks of life, and one or two feeds were omitted. It seemed that even at $80 \%$ of the previously used feeding scale the bulkiness of the diets was excessive and that some further adjustment of food intake would be desirable in future experiments with this type of diet. Table 5 summarizes the results.

Table 6. Expt 6. Summary of results

\begin{tabular}{|c|c|c|c|c|c|c|}
\hline \multirow[b]{2}{*}{ Energy source } & \multicolumn{3}{|c|}{ Diet } & \multicolumn{3}{|c|}{ Least significant difference } \\
\hline & $\begin{array}{l}\mathrm{U} \\
\text { Glucose }\end{array}$ & $\begin{array}{c}\mathrm{V} \\
\text { Melted } \\
\text { lard }\end{array}$ & 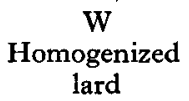 & $P<0.05$ & $P<0.0 \mathrm{r}$ & $P<0.001$ \\
\hline No. of piglets & 6 & 6 & 6 & - & - & - \\
\hline Mean 2nd-day weight (lb) & $4 \cdot 22$ & $4 \cdot 05$ & 4.01 & - & - & - \\
\hline $\begin{array}{l}\text { Mean daily gain from } 2 \text { nd to } \\
\text { 8th day (lb) }\end{array}$ & 0.239 & 0.109 & 0.156 & 0.048 & 0.068 & 0.098 \\
\hline $\begin{array}{l}\text { Mean food eaten/lb gain, } \\
\text { 2nd to } 8 \text { th day }(\mathrm{lb})\end{array}$ & r.55 & 4.43 & 172 & $3.5^{\circ}$ & - & - \\
\hline $\begin{array}{l}\text { Mean daily gain from } \\
\text { 2nd to } 14 \text { th day (lb) }\end{array}$ & 0.336 & 0.216 & 0.241 & 0.079 & 0.112 & 0.163 \\
\hline $\begin{array}{l}\text { Mean food eaten/lb gain, } \\
\text { 2nd to I4th day (lb) }\end{array}$ & $I \cdot 3 I$ & $1 \cdot 29$ & $1 \cdot 27$ & 0.44 & - & - \\
\hline
\end{tabular}

Gain in weight. Growth curves for the four treatments are shown in Fig. 3. Rates of gain in weight were found to have been influenced by differences in initial weight owing to a mistake in the allocation of piglets to the experimental treatments. Weight gains were adjusted after analysis of covariance. Fig. 4 shows relative weight gains after adjustment for differences in 2-day weight. From Fig. 4 and Table 5 it can be seen that growth rate was significantly improved by increasing the level of protein up to $30.8 \%$, and that the effects of the different diets were fully evident by i 4 days of age.

Economy of food conversion. Significant improvements in growth rate were accompanied by significant improvements in economy of food conversion in every instance except one, namely the comparison between diets $R$ and $S$ over the 2- to 28-day period. When growth and food-conversion figures were taken together it appeared that $30.8 \%$ protein gave the best results with this type of diet. However, there were indications that even higher levels of protein gave slight improvements in weight gain and food utilization. As in Expt 4, economy of food conversion was calculated over successive short intervals throughout the experiment. The mean values for piglets on the four diets, plotted against age, are given in Fig. 5. With diets $\mathrm{R}, \mathrm{S}$ and $\mathrm{T}$ economy of food conversion improved rapidly and reached a plateau at the end of the ist week of life. With diet $\mathrm{Q}$, however, improvement was slower and piglets were 2 weeks old before maximum economy was achieved. 


\section{Experiment 6}

The new feeding scale was found to be quite satisfactory. There was considerable variability in the performance of piglets on each of the high-fat diets, whereas those on the low-fat diet showed much more uniform growth and economy of food conversion. Table 6 summarizes the results.

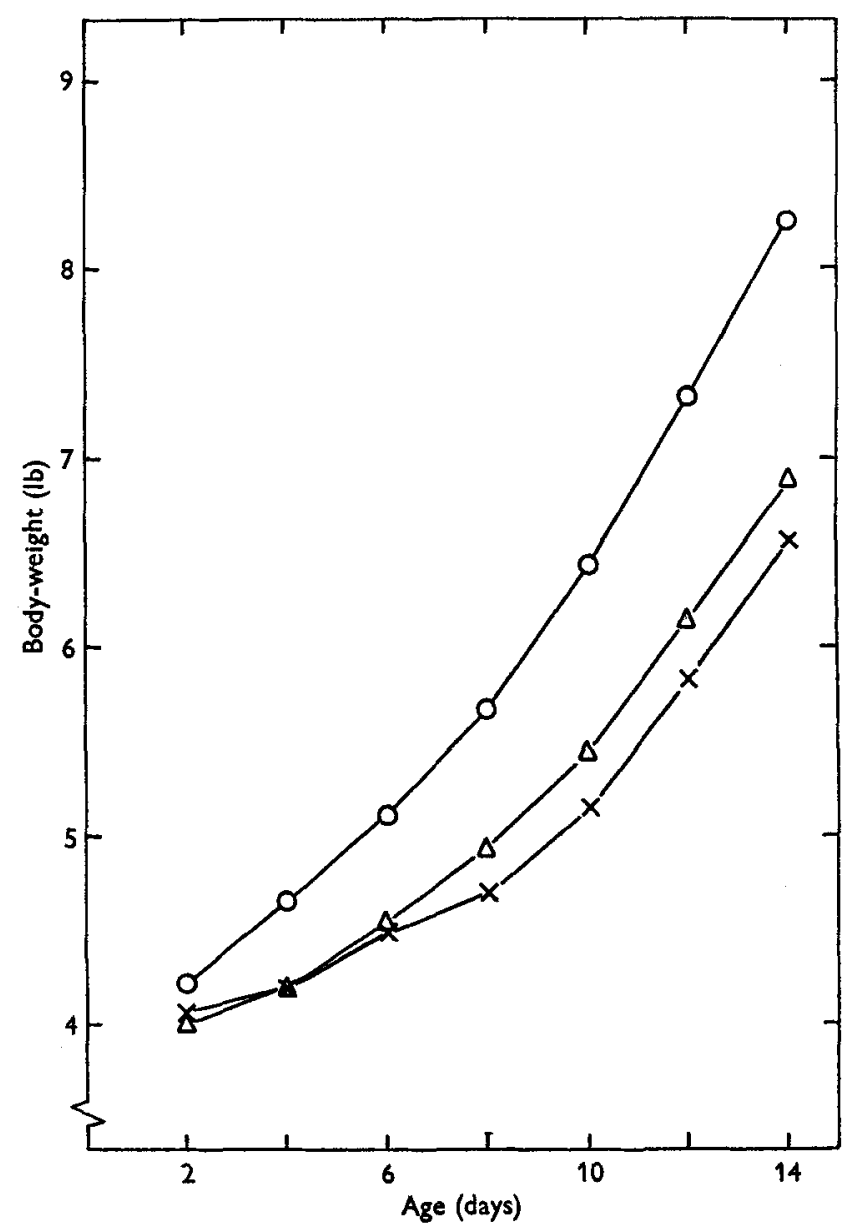

Fig. 6. Expt 6. Mean growth curves for groups of six piglets. $\circ-0$, diet $U$ (glucose); $x-x$, diet $V$ (melted lard); $\Delta-\Delta$, diet W (homogenized lard).

Gain in weight. Mean growth curves for the piglets on the three diets are shown in Fig. 6. Piglets on diets $\mathrm{V}$ and $\mathrm{W}$ gained weight more slowly than those on diet $\mathrm{U}$ during the first half of the experiment $(P<0.01)$. The difference in growth rate between piglets on diets $\mathrm{V}$ and $\mathrm{W}$ over the same period did not quite reach statistical significance. Despite improved growth on the high-fat diets during the second half of the experiment, the differences in growth rate between animals on diet $U$ and those on diets $\mathrm{V}$ and $\mathrm{W}$ were still significant $(P<0.05)$ over the 2- to I4-day period.

Economy of food conversion. Fig. 7 shows the economy of food conversion of the 
piglets at 2-day intervals during the experiment. With diets $\mathrm{V}$ and $\mathrm{W}$ economy of food conversion was very variable and hence the differences between values with the different diets were not statistically significant. As in Expt 4, there was no indication of any advantage in the replacement of carbohydrate by lard. From Fig. 7 it can be seen that during the last 4 days of the experiment the piglets on diet $\mathrm{V}$ made efficient

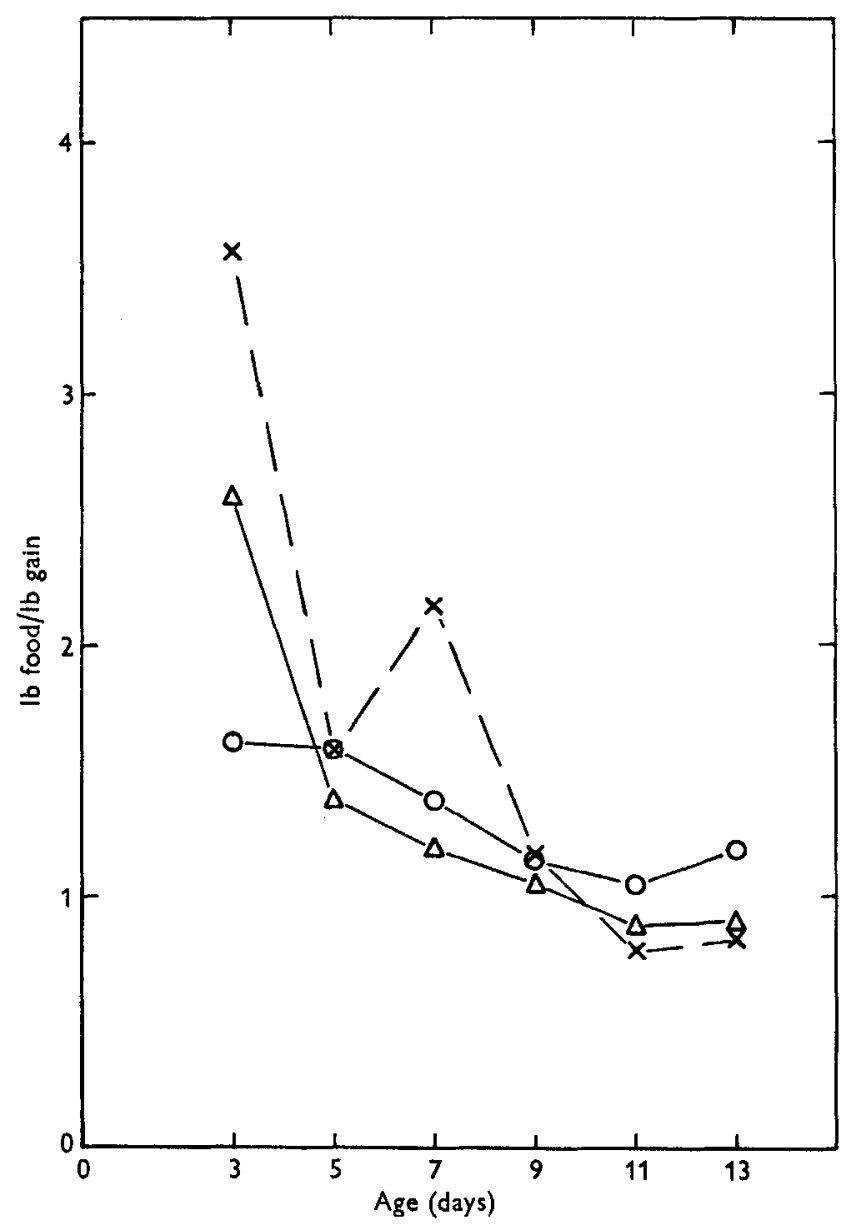

Fig. 7. Expt 6. Changes in economy of food conversion of piglets with increasing age. $\circ-0$, diet $U$ (glucose); $\times---x$, diet $V$ (melted lard); $\Delta-\Delta$, diet $W$ (homogenized lard).

use of their food. This observation indicated that by the roth day of life there was a considerable change in the ability of the piglets to utilize lard that had been added in a melted form.

\section{DISCUSSION}

When comparison is made between the levels of protein that we have found best for diets containing different levels of fat and those reported by other workers, it should be remembered that the relative proportions of casein and whole-milk proteins have varied within experiments and from one experiment to another. With dried 
skim milk as the sole source of protein in diets containing $5 \%$ maize oil, Becker, Ullrey \& Terrill (1954) found $22 \%$ protein to be the optimum. In our earlier Expts I, 2 and 3 (Manners \& McCrea, 1962), in which casein was the major source of protein in diets low in fat, we found $25 \%$ protein to be necessary during the first 4 weeks of life. It is generally accepted that the mixture of proteins in milk has a higher biological value than casein, which would explain the small discrepancy between these results. In Expt 5, in which dried whole milk was used to provide $2 \mathrm{r} \%$ of dietary fat, the optimum protein level was $3 \mathrm{I} \%$ for the rst month of life. This finding is not very different from that of Sewell, Sheffy, Eggert \& Loosli (1953) who found $32 \%$ protein to be the optimum with diets containing $24.6 \%$ lard. Reber, Whitehair \& MacVicar (1953), using diets containing a very high level of lard (35-49\%), found a protein requirement of $4 \mathrm{r} \%$. All the results mentioned above are consistent with the hypothesis that the protein requirement of baby pigs varies according to the calorie density of the diet.

On the basis of Perrin's (1954) values for the composition of sow's milk during the 2nd week of lactation, it can be calculated that there is much less protein per unit of energy in sow's milk than is necessary to support optimum performance on artificial diets. Sow's milk has already been shown to be deficient in iron (Venn, McCance \& Widdowson, 1947) and to contain vitamin C unnecessarily (Braude, Kon \& Porter, I950), so that the postulation of a further imbalance of nutrients is not unreasonable, and it is possible that sow's milk may contain suboptimal amounts of protein. In support of this hypothesis, it may be said that the protein content of the dry matter of sow's milk increases as lactation advances from the 3 rd week onwards (Perrin, 1954), whereas the protein requirement of the piglet has been found to fall with advancing age (Reber et al. 1953; Becker et al. 1954). It is possible that the amino acid composition of sow's milk may be superior to that of the protein used in artificial diets. Sow's-milk proteins are richer in arginine and lysine than is casein; on the other hand, the proteins in cow's milk are richer in lysine than are sow's-milk proteins (Harvey, 1956). The requirement for lysine of piglets weaned at 14 days has been found to be $6.6 \%$ of the dietary protein (Hutchinson, Jensen, Terrill, Becker \& Norton, 1957), which is less than the amount provided by casein. So from this evidence casein should provide adequate amounts of lysine, and arginine remains the only essential amino acid provided in smaller amounts by artificial diets. A very important difference between sow-reared piglets and piglets reared experimentally on artificial diets is in frequency of feeding, which could explain why sow-reared piglets grow so well on a diet containing an energy:protein ratio wider than that found best with artificial diets. In early lactation, piglets suckle their dams at approximately hourly intervals (Barber, Braude \& Mitchell, 1955), whereas artificially reared piglets are rarely fed more than four times a day, usually with a long night interval. Our piglets were fed only twice daily. It has been shown by Braude, Dollar, Mitchell, Porter \& Walker (1958) that, though proteolytic activity of the stomach contents of piglets does not increase over the first 5 weeks of life, that of intestinal contents increases very considerably. In the presence of limited amounts of proteolytic enzymes the efficiency of digestion of protein from sow's milk given in twenty-four evenly spaced 
feeds might be expected to be greater than that of protein given in relatively large feeds at infrequent intervals.

In Expt 4 the performance of piglets was not improved when the energy content of the diets was raised by the replacement of $9 \%$ maize starch with melted lard. If the potential energy value of the high-fat diets had been utilized, improved growth and economy of food conversion would have been expected. The high-fat diets were troublesome to prepare and were not eaten as readily as the low-fat control diet. In the first 2 weeks of life the piglets on diet $\mathrm{M}$ grew faster, and converted their food more efficiently, than those on the high-fat diet $\mathrm{O}$. The higher level of protein in $\operatorname{diet} \mathrm{P}$ enabled piglets to grow as rapidly as those on $\operatorname{diet} \mathrm{M}$, but they still needed as much food per unit weight increase. There is no advantage in increasing the energy and protein content of a diet unless it causes growth to be more rapid, or food conversion to be more economical. The results of Expt 4 are supported by those of Peo, Ashton, Speer \& Catron (1957) who found that, over the period from 8 to 22 days of age, the addition of lard to dry diets increased the amount of food needed per unit weight gain. Over the 8- to 36-day period, these authors found that the effects of added lard on economy of food conversion were no longer significant. However, as in Expt 4, there was no indication of any beneficial effect from the addition of lard (apart from improved appearance of piglets and improved diet texture) in the work of Peo et al. (1957). Smith \& Lucas (1956-7) found no improvement in growth or economy of food conversion when arachis oil was added to a dry diet for weaning at to days. On the other hand, Crampton \& Ness (1954) reported improved growth and food conversion economy when maize oil was added to a very similar diet. The addition of $20 \%$ melted lard in Expt 6 gave results confirming those obtained when melted lard was added in Expt 4. Economy of food conversion by piglets on the diet containing melted lard was very poor at first, and it was about a week before they began to utilize this diet efficiently. As a result their growth lagged seriously behind that of piglets on the control low-fat diet. Performance of piglets on the diet containing homogenized lard was little better than of those on the diet with melted lard. The design of Expt 6 was such that the differences observed were not complicated by variations in energy:protein ratio between diets or by differing intake of energy, protein, minerals or vitamins. It therefore appears that, under conditions of twice-daily feeding, dietary lard is poorly utilized by piglets in the rst week of life. In the dry matter of sow's milk there is from 40 to $50 \%$ fat (Perrin, 1954). Barber et al. (1955) found the dry-matter intake per unit live-weight gain in sow-reared piglets to be $0.77,0.80$ and 0.86 units in the Ist, 2nd and $3^{\text {rd }}$ weeks of life, respectively. Thus the sow-reared piglet, unlike the piglets in Expts 4 and 6, has no difficulty in utilizing a high-fat diet during the rst week of life. Sheffy, Phillips, Dymsza, Grummer \& Bohstedt (1952) showed that sow's milk had analytical constants very similar to those of lard. However, this resemblance does not extend to fatty acid composition. For example, lard contains three times as much stearic acid as does sow's milk fat (Garton, 1960), and differences in fatty acid composition may explain why lard was poorly utilized in our experiments and in those of Peo et al. (1957).

Poor utilization of food in the Ist week of life was not confined in our experiments 
to the piglets on high-fat diets. Diet $M$ in Expt 4 and diet $U$ in Expt 6 were also less well utilized in the Ist week of life than in the later part of the experiments. Production of digestive enzymes, lipase and lactase excepted, appears to increase with age (see Lucas \& Lodge, I96r), which could explain poor utilization of diets under a twicedaily feeding schedule. Stomach capacity is another factor likely to be limiting, in the utilization of food by piglets fed only twice daily. Newlander \& Jones (r935) found that the mean stomach capacity of sixteen 2-day-old piglets averaging I029 $\mathrm{g}$ weight was $29.8 \mathrm{ml}$. Barber et al. (I955) found that the mean amount of milk obtained at a single suckling was $25.6 \mathrm{~g}$, which agrees well with the figure of $28.2 \mathrm{~g}$ calculated from the data of Berge \& Indrebø (I953). Thus sow-reared piglets should have no difficulty in accommodating the usual amount of milk obtained at one suckling. On the other hand, the artificially reared piglets in our experiments received large amounts of food in two irregularly spaced meals. In other (unpublished) experiments we have found that, under the same feeding regime, artificially reared piglets had $2 \frac{1}{2}$ times the stomach capacity of their sow-reared litter-mates at 4 weeks of age. A possible explanation of the success of twice-daily feeding in our experiments, when many other workers have used more frequent feeding, especially during the rst week of life, is that we have maintained the solids content of the gruels at the highest possible level so that bulk intake was minimal. In Expt 5 , in which it was found necessary to dilute the diets with $3 \mathrm{ml}$ water/g diet, the bulk intake of piglets was excessive, and did appear to be the cause of food refusals and occasional scouring. If overloading of the digestive tract is a factor causing inefficient utilization of food it would be expected to exert its effect on absorption as well as digestion. It would be interesting to compare the performance of piglets given the same diet twice daily or hourly. However, for practical purposes hourly feeding would be prohibitively expensive, even if shown to be desirable.

In both Expts 4 and 6 the replacement of carbohydrate with lard severely depressed growth. The standard of hygiene maintained in these experiments was such that, with two exceptions, piglets survived the period of poor food utilization without ill effects. Presumably the maturation of the digestive system of the piglet proceeds steadily from birth onwards, and it seems reasonable to suppose that the effects seen in Expts 4 and 6 would have been even more marked, possibly even fatal, in piglets weaned at birth. The inability of many workers to rear piglets without colostrum, or, indeed, sometimes to rear 2- or 3-day-old piglets on artificial diets may well be related to their assumption that it is necessary to provide a high-fat diet.

In conclusion it can be said that it is in the first 2 weeks of life of a piglet that some of the most interesting nutritional problems remain, and it is likely that these problems are due to the immaturity of the piglet's digestive system at this time. In the past too many assumptions have been made in the formulation of artificial diets for piglets. The limitations imposed by twice- and thrice-daily feeding have not always been appreciated. A great deal of work has been done with simulated milk diets despite the fact that the preparation of such diets is so laborious that they are of little practical significance. Our experiments refute the assumption that such diets are likely to be ideal. A simple low-fat diet consisting of glucose, dried separated milk and casein, 
supplemented with minerals and vitamins, appears at the present time to be the best from all points of view during the Ist fortnight of life.

\section{SUMMARY}

r. Twenty-four piglets were used in an experiment to determine the protein requirement of baby pigs on high-fat diets. The diets were based on dried whole milk and contained $2 x \%$ fat. Crude protein levels of $19 \cdot 6,24 \cdot 0,30.8$ and $37.0 \%$ were compared over the period from 2 to 28 days of age. The $30.8 \%$ level gave optimum growth and economy of feed conversion over both the 2- to 14 -day and 2- to 28 -day periods.

2. The effect of the replacement of dietary carbohydrate with lard was studied in two experiments with a total of fifty piglets. In both experiments the replacement of carbohydrate with lard that had been melted before mixing was found to depress growth and economy of feed conversion. In the second experiment a similar depression was observed when homogenized lard replaced the carbohydrate.

3. Our own findings concerning the protein requirement of piglets over the Ist month of life have been compared with those of other workers. A considerable measure of agreement was found when protein requirement was related to the energy content of the diet. The energy:protein ratio found to be optimum was always narrower than that in sow's milk.

4. The apparent inability of the piglets to utilize dietary lard under conditions of twice-daily feeding is discussed.

We thank Dr D. E. Kidder and Mr A. D. Osborne for their continued advice and assistance.

\section{REFERENCES}

Barber, R. S., Braude, R. \& Mitchell, K. G. (1955). F. agric. Sci. 46, 97.

Becker, D. E., Ullrey, D. E. \& Terrill, S. W. (1954). F. Anim. Sci. 13, 346.

Berge, S. \& Indrebø, T. (I953). Meld. Norg. LandbrHøisk. 33, $3^{89}$.

Braude, R., Dollar, A. M., Mitchell, K. G., Porter, J. W. G. \& Walker, D. M. (1958). Proc. Nutr. Soc. I7, xlix.

Braude, R., Kon, S. K. \& Porter, J. W. G. (1950). Brit. F. Nutr. 4, 186.

Crampton, E. W. \& Ness, O. M. (1954). F. Anim. Sci. 13, 357.

Garton, G. A. (1960). Nutr. Abstr. Rev. 30, r.

Harvey, D. (1956). Tech. Commun. Bur. Anim. Nutr., Aberd., no. I9.

Hawk, P. B., Oser, B. L. \& Summerson, W. N. (1954). Practical Physiological Chemistry, 13th ed. London: J. and A. Churchill.

Hutchinson, H. D., Jensen, A. H., Terrill, S. W., Becker, D. E. \& Norton, H. W. (1957). F. Anim. Sci. I6, 553 .

Lucas, I. A. M. \& Lodge, G. A. (1961). Tech. Commun. Bur. Anim. Nutr., Aberd., no. 22.

Manners, M. J. \& McCrea, M. R. (1962). Brit. F. Nutr. 16, 475 .

Maynard, L. A. (1944). F. Nutr. 28, 443 .

Newlander, J. A. \& Jones, C. H. (1935). Bull. Vt agric. Exp. Sta. no. 389.

Peo, E. R. Jr., Ashton, G. C., Speer, V. C. \& Catron, D. V. (1957). F. Anim. Sci. r6, 885.

Perrin, D. R. (1954). F. Dairy Res. 21, 55.

Reber, E. F., Whitehair, C. K. \& MacVicar, R. (1953). F. Nutr. 50, 45 I.

Sewell, R. F., Sheffy, B. E., Eggert, R. G. \& Loosli, J. K. (1953). F. Anim. Sci. 12, 597.

Sheffy, B. E., Phillips, P. H, Dymsza, H. A., Grummer, R. H. \& Bohstedt, G. (1952). F. Anim. Sci. II, 727.

Smith, H. \& Lucas, I. A. M. (1956-7). F. agric. Sci. 48, 220.

Venn, J. A. J., McCance, R. A. \& Widdowson, E. M. (1947). F. comp. Path. 57, 314.

Widdowson, E. M. (1955). Proc. Nutr. Soc. 14, 142. 